\title{
UJI DAYA HAMBAT EKSTRAK KULIT BUAH MANGGIS (Garcinia mangostana L.) TERHADAP PERTUMBUHAN Candida albicans SECARA IN VITRO (STUDI EKSPERIMEN DI LABORATORIUM MIKROBIOLOGI FARMASI UNIVERSITAS MUSLIM INDONESIA 2017)
}

\author{
Chusnul Chotimah, Diah Wahyuni, Nurasisa Lestari
}

Fakultas Kedokteran Gigi Universitas Muslim Indonesia, Makassar

Email: choirunisabasnawi@gmail.com

\begin{abstract}
ABSTRAK
Latar Belakang: Kesehatan gigi dan mulut penting untuk diperhatikan. Berdasarkan provinsi tahun 2013 yang mempunyai masalah gigi dan mulut yang cukup tinggi (>35\%) adalah provinsi Sulawesi Selatan, Kalimantan Selatan dan Sulawesi Tengah dengan EMD 10,3\%, 8\%, dan 6,4\%. Candida albicans merupakan flora normal yang dapat ditemukan dalam rongga mulut yang sehat, tetapi dapat menjadi pathogen apabila didukung oleh kondisi penurunan respon imun. Kulit buah manggis memiliki efek sebagai antifungi karena mempunyai kandungan aktif berupa alkaloida, saponin, flavonoid, tanin, triterpenoid dan steroid. Tujuan: Mengetahui daya hambat ekstrak kulit buah manggis (Garcinia mangotana L.) terhadap pertumbuhan Candida albicans secara in vitro. Metode: Penelitian ini adalah Eksperimental Laboratoris dengan desain post test only control group design. Sampel penelitian adalah biakan murni jamur Candida albicans di Laboratorium Mikrobiologi Farmasi UMI. Hasil: Hasil ekstrak kulit buah manggis konsentrasi 0,1\% 0,5\% 2,5\% dan 12,5\% mempunyai daya antifungi terhadap Candida albicans. Hasil uji One Way Anova didapatkan nilai $p=0,000(p<0,05)$. Kesimpulan: Diameter zona hambat jamur $\underline{\text { Candida albicans }}$ akan semakin besar seiring dengan peningkatan konsentrasi esktrak kulit buah manggis.
\end{abstract}

Kata kunci: Kulit Buah Manggis (Garcinia mangostana L.), Candida albicans, zona daya hambat.

\section{PENDAHULUAN}

Kesehatan gigi dan mulut penting untuk diperhatikan dan merupakan bagian integral dari kesehatan secara keseluruhan yang memerlukan penanganan segera sebelum terlambat dan dapat mempengaruhi kondisi kesehatan seseorang. Berdasarkan provinsi pada tahun 2013 yang mempunyai masalah gigi dan mulut yang cukup tinggi $(>35 \%)$ adalah provinsi Sulawesi Selatan, Kalimantan Selatan dan Sulawesi Tengah dengan EMD 10,3\%, $8 \%$ dan $6,4 \%{ }^{1}$

Rongga mulut merupakan
habitat sejumlah besar
mikroorganisme yang


Uji daya hambat ekstrak kulit buah manggis (Garcinia mangostana L.) terhadap pertumbuhan Candida albicans secara In Vitro

berdampingan satu sama lain sebagai mikrobiota normal. Ada lebih dari 20 spesies Candida, yang paling umum adalah jamur mulut oportunistik yang terjadi pada individu yang sehat adalah Candida albicans. Candida albicans merupakan flora normal yang dapat ditemukan dalam rongga mulut yang sehat, tetapi dapat menjadi pathogen apabila didukung oleh lingkungan dengan kondisi penurunan respon imun atau terjadi perubahan ekosistem mikroorganisme. ${ }^{2,3}$

Candida albicans adalah spesies fungi yang ditemukan pada berbagai bagian tubuh orang yang sehat, seperti di dalam mulut, kerongkongan, dibawah kuku dan kulit. Candida albicans menyebabkan infkesi rongga mulut apabila terdapat faktor predisposisi pada tubuh inang. Faktorfaktor yang memungkinkan terjadinya infeksi jamur Candida antara lain kondisi tubuh yang lemah.,5

Beberapa penyakit yang disebabkan oleh Candida albicans diantaranya adalah sariawan. Sariawan merupakan suatu penyakit yang umum diderita oleh seseorang dan merupakan infeksi pada jaringan mukosa mulut yang sering terjadi secara berulang, dikenal dengan nama Stomatitis Aftosa Rekuren
(SAR). Meskipun bukan merupakan suatu penyakit berbahaya, namun sering kali sariawan menganggu aktivitas makan dan berbicara. Sariawan disebabkan oleh karena pertumbuhan jamur Candida albicans yang berlebihan. ${ }^{5,6}$

Selain itu penyakit kandidiasis oral adalah infeksi oportunistik yang sering terjadi pada rongga mulut yang disebabkan karena pertumbuhan jamur Candida albicans. Lesi kandidiasis ini dapat berkembang disetiap rongga mulut, tetapi lokasi yang paling sering adalah mukosa bukal, lipatan mukosa bukal, orofaring dan lidah. Penyakit ini sering ditemui pada pasien dengan infeksi HIV/AIDS. Menurut laporan World Health Organization (WHO) tahun 2001 frekuensi kandidiasis oral antara $5,8 \%$ sampai $98,3 \% .^{7,8}$

Telah banyak dilakukan penelitian dengan memanfaatkan bahan alam yang bertujuan untuk mendukung program kesehatan gigi. Kembalinya perhatian kebahan alam atau (back to nature), dianggap sebagai hal yang sangat bermanfaat karena selain masyarakat telah percaya bahwa bahan alam mampu mengobati berbagai macam penyakit. Pemanfaatan bahan alam yang digunakan sebagai obat juga jarang 
Uji daya hambat ekstrak kulit buah manggis (Garcinia mangostana L.) terhadap pertumbuhan Candida albicans secara In Vitro

menimbulkan efek samping dibandingkan obat yang terbuat dari sintesis. ${ }^{9}$

Salah satu bahan alam yang dikonsumsi masyarakat adalah manggis (Garcinia mangostana L.). Manggis merupakan tanaman yang hampir seluruh bagian tanamannya dapat dimanfaatkan, mulai dari daging buah, kulit buah, daun, batang hingga akar. Kulit buah manggis mengandung berbagai kandungan metabolit sekunder yang memperlihatkan aktivitas biologis tertentu. Kulit buah manggis memiliki efek farmakologis salah satunya sebagai antifungal. Hal ini dikarenakan pada kulit buah manggis terdapat kandungan antifungal dan antibakteri yaitu senyawa fenol. Menurut penelitian yang ada, dilaporkan bahwa ekstrak etanol $96 \%$ kulit buah manggis mengandung senyawa kimia golongan alkaloida, flavonoid, glikosida, saponin, tannin dan steroid/tritepenoid. ${ }^{10,11}$

\section{METODE PENELITIAN}

\section{Waktu dan Tempat Penelitian}

Penelitian ini dilakukan di Laboratorium Mikrobiologi Farmasi Universitas Muslim Indonesia pada bulan Januari-Februari 2017.
Pada penelitian ini teknik pengambilan sampel adalah Purposive Sampling dimana pengambilan sampel dilakukan dengan sengaja sesuai dengan persyaratan sampel yang dibutuhkan. Subjek dari penelitian ini adalah jamur Candida albicans. Variabel bebas ialah ekstrak kulit manggis (Garcinia Mangostana L.), dan Klorheksidin dengan pelarut akuades. Variabel terikat adalah jamur Candida albicans. Candida albicans merupakan bakteri murni yang diperoleh dari Laboratorium Mikrobiologi Farmasi UMI. Ekstrak kulit buah manggis (Garcinia Mangostana L.) adalah ekstrak yang diperoleh dari metode maserasi dengan menggunakan pelarut etanol 96\%. Klorheksidin merupakan antibiotik yang tersedia dalam bentuk tablet di Laboratorium Mikrobiologi Farmasi UMI.

\section{Alat dan Bahan}

Alat-alat yang digunakan dalam penelitian ini yaitu labu erlenmeyer, cawan petri, gelas kimia $500 \mathrm{~mL}$, lampu spirtus, tabung reaksi, botol vial, jangka sorong, alumunium voil, plastik wrap, autoclave, oven, timbangan analitik, masker, handscoen, batang pengaduk, sendok tanduk, ose bulat, paper disk, spektrofotometer, inkubator, spoit dan 
Uji daya hambat ekstrak kulit buah manggis (Garcinia mangostana L.) terhadap pertumbuhan Candida albicans secara In Vitro

hairdrier. Bahan-bahan yang digunakan dalam penelitian ini kulit buah manggis, jamur Candida albicans, DMSO, klorheksidin, PDA, etanol 96\%.

\section{Prosedur Kerja}

Ekstrak kulit manggis diperoleh dengan cara buah manggis dibersihkan dan dipisahkan kulit luar dan daging buah, kulit buah dipotongpotong dan dikeringkan dengan cara dijemur, dihaluskan dengan menggunakan alat blender sampai diperoleh serbuk kulit manggis yang halus. Setelah diperoleh hasil berupa serbuk halus dari kulit buah Manggis, kemudian diekstrak dengan cara ditimbang 350 gram serbuk kulit manggis, dimasukan dalam toples dan dimaserasi dengan etanol $96 \%$ sebanyak $2625 \mathrm{~mL}$ sampai serbuk sampel terendam, ditutup dan dibiarkan selama 3 hari sambil sesekali diaduk kemudian maserat disaring ke dalam toples. Ampas dibilas menggunakan etanol $90 \%$ sampai memperoleh maserat $3500 \mathrm{~mL}$ dan tutup wadah dibiarkan selam 3 hari. Maserat disaring dan dipekatkan dengan menggunakan hairdrier. Kemudian penelitian dilanjutkan dengan melakukan pengenceran. Pengenceran bertujuan untuk menghasilkan beberapa konsentrasi yang akan digunakan dari ekstrak kulit buah manggis yang dapat menghambat pertumbuhan jamur Candida albicans dan zona penghambatnya. Ekstrak kulit buah manggis kemudian ditimbang sesuai dengan konsentrasi. Setelah itu campurkan $10 \mathrm{~mL}$ DMSO kedalam masing-masing ekstrak. Dalam penelitian ini dibuat pengenceran sebanyak 4 konsentrasi yaitu: $0,1 \%$, 0,5\%, 2,5\%, 12,5\% dengan DMSO sebagai pengencer. Jamur Candida albicans yang digunakan dalam penelitian ini disimpan pada medium Potato Dextrose Agar (PDA) kemudian tuang ke dalam cawan petri dan biarkan memadat pada suhu kamar.

Lalu adapun prosedur uji daya hambat yaitu siapkan 4 buah cawan petri steril yang telah diisi oleh medium, lalu ambil isolate murni yang telah dipersiapkan dengan menggunakan ose bulat kemudian digoreskan ke medium PDA. Selanjutnya ambil 4 buah paper disc dan kemudian direndam pada botol vial yang telah berisi konsentrasi ekstrak kulit buah manggis. Paper disc diletakkan di atas cawan petri yang berisi populasi jamur Candida albicans dan selanjutnya diinkubasi selama 48 jam pada suhu $37^{\circ} \mathrm{C}$. Setelah diinkubasi, dan diamati. 
Uji daya hambat ekstrak kulit buah manggis (Garcinia mangostana L.) terhadap pertumbuhan Candida albicans secara In Vitro

\section{HASIL PENELITIAN}

Tabel 1. Diameter zona hambat jamur Candida albicans

\begin{tabular}{ccccccc}
\hline Replikasi & \multicolumn{2}{c}{$\begin{array}{c}\text { Kelompok Kontrol } \\
(\mathbf{m m})\end{array}$} & & & \multicolumn{3}{c}{$\begin{array}{c}\text { Kelompok Konsentrasi } \\
(\mathbf{m m})\end{array}$} \\
& $\mathbf{K}(+)$ & $\mathbf{K}(-)$ & $\mathbf{0 , 1} \%$ & $\mathbf{0 , 5} \%$ & $\mathbf{2 , 5} \%$ & $\mathbf{1 2 , 5 \%}$ \\
\hline 1 & $18,31 \mathrm{~mm}$ & $0 \mathrm{~mm}$ & $7,51 \mathrm{~mm}$ & $8,83 \mathrm{~mm}$ & $11,44 \mathrm{~mm}$ & $14,05 \mathrm{~mm}$ \\
2 & $15,76 \mathrm{~mm}$ & $0 \mathrm{~mm}$ & $8,37 \mathrm{~mm}$ & $8,54 \mathrm{~mm}$ & $11,75 \mathrm{~mm}$ & $13,26 \mathrm{~mm}$ \\
3 & $16,28 \mathrm{~mm}$ & $0 \mathrm{~mm}$ & $8,09 \mathrm{~mm}$ & $8,64 \mathrm{~mm}$ & $11,80 \mathrm{~mm}$ & $13,02 \mathrm{~mm}$ \\
4 & $15,86 \mathrm{~mm}$ & $0 \mathrm{~mm}$ & $7,92 \mathrm{~mm}$ & $8,53 \mathrm{~mm}$ & $11,36 \mathrm{~mm}$ & $14,06 \mathrm{~mm}$ \\
\hline
\end{tabular}

Sumber : Data primer, 2017

Tabel 2. Rata-rata diameter zona hambat jamur Candida albicans dengan konsentrasi $0,1 \%, 0,5 \%, 2,5 \%$ dan $12,5 \%$.

\begin{tabular}{lcccc}
\hline Kelompok & Mean & $\begin{array}{c}\text { Std } \\
\text { Deviation }\end{array}$ & Median & Min-Max \\
\hline Ekstark Kulit Buah Manggis 0,1\% & 7,972 & 0,359 & 8,005 & $7,51-8,37$ \\
Ekstrak Kulit Buah Manggis 0,5\% & 8,635 & 0,139 & 8,590 & $8,53-8,83$ \\
Ekstrak Kulit Buah Manggis 2,5\% & 11,587 & 0,219 & 11,595 & $11,36-11,80$ \\
Ekstrak Kulit Buah Manggis 12,5\% & 13,597 & 0,537 & 13,655 & $13,02-14,06$ \\
& & & & 16,070 \\
\hline Kontrol Positif & 16,552 & 1,193 & $15,76-8,31$ \\
Kontrol Negatif & 0,000 & 0,000 & 0,000 & $0,00-0,00$ \\
\hline
\end{tabular}

Sumber : Data Primer, 2017

Tabel 3. Perbedaan efek ekstrak kulit buah manggis (Garcinia mangostana L.) dengan kontrol negatif pada pertumbuhan Candida albicans.

\begin{tabular}{lcc} 
Kelompok & Mean Difference & p Value \\
\hline Ekstrak Kulit Buah Manggis 0,1\% - Kontrol Negatif & 7,972 & 0,000 \\
Ekstrak Kulit Buah Manggis 0,5\% - Kontrol Negatif & 8,635 & 0,000 \\
Ekstrak Kulit Buah Manggis 2,5\% - Kontrol Negatif & 11,587 & 0,000 \\
Ekstrak Kulit Buah Manggis 12,5\% - Kontrol Negatif & 13,597 & 0,000 \\
\hline
\end{tabular}

Sumber : Data Primer, 2017

Tabel 4. Perbedaan efek zona hambat ekstrak kulit buah manggis (Garcinia mangostana L.) dengan kontrol positif pada pertumbuhan Candida albicans.

\begin{tabular}{lcc}
\hline Kelompok & Mean Difference & p Value \\
\hline Ekstrak Kulit Buah Manggis 0,1\% - Kontrol Positif & 8,580 & 0,000 \\
Ekstrak Kulit Buah Manggis 0,5\% - Kontrol Positif & 7,917 & 0,000 \\
Ekstrak Kulit Buah Manggis 2,5\% - Kontrol Positif & 4,965 & 0,000 \\
Ekstrak Kulit Buah Manggis 12,5\% - Kontrol Positif & 2,955 & 0,000 \\
\hline
\end{tabular}

Sumber : Data, Primer 2017 
Uji daya hambat ekstrak kulit buah manggis (Garcinia mangostana L.) terhadap pertumbuhan Candida albicans secara In Vitro

Tabel 5. Perbedaan zona hambat Candida albicans pada ekstrak kulit buah manggis (Garcinia mangostana L.) dengan berbagai konsentrasi.

\begin{tabular}{lcc}
\hline Kelompok & Mean Difference & p Value \\
\hline Ekstrak Kulit Buah Manggis 0,1\% - 0,5\% & 0,662 & 0,572 \\
Ekstrak Kulit Buah Manggis 0,1\% - 2,5\% & 3,615 & 0,000 \\
Ekstrak Kulit Buah Manggis 0,1\%- $12,5 \%$ & 5,625 & 0,000 \\
Ekstrak Kulit Buah Manggis 0,5\%-2,5\% & 2,952 & 0,000 \\
Ekstrak Kulit Buah Manggis 0,5\%- $12,5 \%$ & 4,962 & 0,000 \\
Ekstrak Kulit Buah Manggis 2,5\% - 12,5\% & 2,010 & 0,001 \\
\hline Sumber : Data Primer, 2017 & &
\end{tabular}

Pada tabel 1 menunjukkan bahwa zona hambat mulai terbentuk pada konsentrasi $0,1 \%$ begitu juga dengan konsentrasi $0,5 \%, 2,5 \%$, dan $12,5 \%$ sudah terlihat peningkatan ukuran zona hambat. Hasil pengukuran pada tabel diatas menunjukkan bahwa pada konsentrasi $0,1 \%$ zona hambat sebesar 7,92 $\mathrm{mm}$ dan konsentrasi $12,5 \%$ menghasilkan zona hambat terbesar yaitu $14,06 \% \mathrm{~mm}$. Tetapi pada tabel menunjukkan bahwa kontrol negatif tidak menunjukkan adanya zona hambat, sedangkan pada kontrol positif menunjukkan adanya zona hambat yaitu sebesar 15,86 mm. Hal ini menunjukkan bahwa lebih besar zona hambat yang dihasilkan kontrol positif dari pada konsentrasi $12,5 \%$ ekstrak kulit buah manggis.

Tabel 2 menunjukkan bahwa konsentrasi diameter Candida albicans pada konsentrasi ekstrak kulit buah manggis $0,1 \%$ rata-rata 7,972 , pada konsentrasi ekstrak kulit buah manggis $0,5 \%$ rata-rata 8,635 , pada konsentrasi ekstrak kulit buah manggis $2,5 \%$ rata-rata 11,587, pada konsentrasi ekstrak kulit buah manggis $12,5 \%$ rata-rata 13,597 . Hal ini menunjukkan bahwa dengan meningkatnya konsentrasi ekstrak kulit buah manggis maka meningkat pula zona hambat yang terbentuk.

Tabel 3 menunjukkan bahwa perbedaan diameter zona hambat Candida albicans pada konsentrasi $0,1 \%$ dan kontrol negatif 7,972 , perbedaan diameter zona hambat Candida albicans pada media ekstrak kulit buah manggis konsentrasi $0,5 \%$ dan kontrol negatif 8,635 , perbedaan diameter zona hambat Candida albicans pada media ekstrak kulit buah manggis konsentrasi 2,5\% dan kontrol negatif 11,587 , perbedaan diameter zona hambat Candida albicans pada media ekstrak kulit buah manggis konsentrasi $12,5 \%$ dan kontrol negatif 13,579. Berdasarkan hasil uji statistic 
Uji daya hambat ekstrak kulit buah manggis (Garcinia mangostana L.) terhadap pertumbuhan Candida albicans secara In Vitro

post hoc dari analisis one way anova didapatkan bahwa nilai $\mathrm{p}=0,000$ untuk ekstrak kulit buah manggis konsentrasi $0,1 \%$, nilai $p=0,000$ untuk ekstrak kulit buah manggis konsentrasi $0,5 \%$, nilai $\mathrm{p}=0,000$ untuk ekstrak kulit buah manggis konsentrasi 2,5\%, nilai $\mathrm{p}=0,000$ untuk ekstrak kulit buah manggis $12,5 \%$. Hal ini menunjukkan bahwa nilai $p$ untuk masing-masing konsentrasi ekstrak $\quad<(\alpha=0,05)$ sehingga dapat disimpulkan bahwa ekstrak kulit buah manggis pada konsentrasi $\quad(0,1 \% \quad 0,5 \% \quad 2,5 \%$ dan $12,5 \%)$ efektif dalam menghambat pertumbuhan jamur Candida albicans.

Tabel 4 menunjukkan terdapat perbedaan diameter zona hambat Candida albicans pada media ekstrak kulit buah manggis konsentrasi $0,1 \%$ dan kontrol positif 8,580 , perbedaan zona hambat Candida albicans pada media ekstrak kulit buah manggis konsentrasi $0,5 \%$ dan kontrol positif 7,917 , perbedaan zona hambat Candida albicans pada media ekstrak kulit buah manggis konsentrasi 2,5\% dan kontrol positif 4,965, perbedaan zona hambat Candida albicans pada media ekstrak kulit buah manggis konsentrasi $12,5 \%$ dan kontrol positif 2,955. Berdasarkan hasil dari uji statistic post hoc dari analisis one way anova maka didapatkan nilai $\mathrm{p}=0,000$ untuk ekstrak kulit buah manggis konsentrasi $0,1 \%$, nilai $p=0,000$ untuk ekstrak kulit buah manggis konsentrasi $0,5 \%$, nilai $p=0,000$ untuk ekstrak kulit buah manggis konsentrasi $2,5 \%$, nilai $p=0,000$ untuk ekstrak kulit buah manggis konsentrasi $12,5 \%$. Hal ini berarti bahwa nilai $\mathrm{p}$ untuk masing-masing konsentrasi ekstrak $<(\alpha=0,05)$ ada perbedaan efektifitas antara ekstrak kulit buah manggis $(0,1 \% 0,5 \% 2,5 \%$ dan 12,5\%) dengan kontrol positif dalam menghambat pertumbuhan jamur Candida albicans, dimana kontrol positif tersebut masih lebih baik dalam menghambat pertumbuhan jamur Candida albicans dibandingkan ekstrak kulit buah manggis.

Tabel 5 menunjukkan bahwa pada perbedaan kelompok konsentrasi antara $0,1 \%$ dengan $0,5 \%$ $(p=0,572)$ tidak berbeda daya hambatnya. Pada konsentrasi $0,1 \%$ dengan $2,5 \% \quad(p=0,000)$, konsentrasi $0,1 \%$ dengan $12,5 \% \quad(p=0,000)$, konsentrasi $\quad 0,5 \%$ dengan $2,5 \%$ $(p=0,000)$, konsentrasi $0,5 \%$ dengan $12,5 \% \quad(p=0,000)$, konsentrasi $2,5 \%$ dengan $12,5 \%(p=0,001)$ memiliki nilai $p<0,05$ sehingga ada perbedaan yang 
Uji daya hambat ekstrak kulit buah manggis (Garcinia mangostana L.) terhadap pertumbuhan Candida albicans secara In Vitro

bermakna pada tiap kelompok konsentrasi.

\section{PEMBAHASAN}

Berdasarkan hasil penelitian yang diperoleh menunjukkan bahwa uji daya hambat ekstrak kulit buah manggis terhadap jamur Candida albicans yaitu konsentrasi $0,1 \% 0,5 \%$ $2,5 \%$ dan $12,5 \%$ masing-masing menunjukkan adanya zona hambat tetapi dengan diameter yang relatif kecil apabila dibandingkan dengan zona hambat disekitar kontrol positif klorheksidin, luas zona hambat ekstrak kulit buah manggis lebih kecil, sedangkan pada aquades sebagai kontrol negatif menunjukkan tidak adanya zona hambat yang terbentuk.

Hasil penelitian yang didapatkan bahwa besarnya zona hambat yang terbentuk terus meningkat seiring dengan bertambah besarnya konsentrasi ekstrak kulit buah manggis. Zona hambat terbesar terdapat pada konsentrasi 12,5\% sedangkan zona hambat terendah terdapat pada konsentrasi $0,1 \%$. Semakin tinggi konsentrasi semakin tinggi pula kandungan zat aktif di dalamnya sehingga aktivitas antijamur akan semakin besar dan juga sebaliknya semakin rendah konsentrasi ekstrak kulit buah manggis maka semakin sedikit kandungan zat aktif di dalamnya sehingga aktivitas antijamur berkurang. Pada kontrol negatif yaitu aquades steril tidak menunjukkan adanya zona bening pada paper disk, sedangkan pada kontrol positif yaitu klorheksidin menunjukkan adanya zona bening yang terbentuk disekitar paper disk dengan rata-rata $16,552 \mathrm{~mm}$. Hal ini menunjukkan bahwa zona bening yang dihasilkan kontrol positif lebih besar dari pada kelompok konsentrasi ekstrak kulit buah manggis. Hasil penelitian yang dilakukan oleh Andayani, dkk (2016), menyatakan bahwa semakin tinggi konsentrasi ekstrak kulit buah manggis maka semakin besar pula kemampuannya untuk menghambat pertumbuhan mikroba. ${ }^{12}$ Potensi daya hambat yang dihasilkan oleh ekstrak kulit buah manggis terhadap pertumbuhan Candida albicans disebabkan oleh zatzat aktif yang terkandung didalam kulit buah manggis seperti flavonoid, tanin, saponin, alkaloid, polifenol, dan triterpenoid yang berfungi sebagai antifungal. ${ }^{12}$

Penelitian yang dilakukan oleh Putra (2014), menyatakan bahwa sifat antimikroba flavonoid disebabkan karena kemampuannya membentuk kompleks dengan dinding sel bakteri. ${ }^{13}$ 
Uji daya hambat ekstrak kulit buah manggis (Garcinia mangostana L.) terhadap pertumbuhan Candida albicans secara In Vitro

Selain itu kandungan manggis yang lain adalah tanin yang dapat membentuk kompleks dengan protein transmembran, enzim-enzim pada permukaan membran, melalui ikatan hidrogen sehingga dapat menganggu kehidupan mikroba. Manggis juga mempunyai kandungan senyawa seperti alkaloid dan steroid. Alkaloid memiliki kemampuan menghambat mikroba dan mekanismenya karena dapat menyebabkan kerusakan DNA. Sedangkan mekanisme kerja steroid dalam menghambat mikroba adalah dengan merusak membran plasma sehingga menyebabkan bocornya sitoplasma ke luar sel yang selanjutnya menyebabkan kematian sel. ${ }^{13}$

Studi fitokimia memperlihatkan bahwa ekstrak manggis mengandung beberapa komponen aktif termasuk kelompok xanthon seperti salah satunya alpha-mangostin. Alphamangostin memiliki potensi untuk pengobatan kandidasis mulut. Hal ini sesuai dengan penelitian yang dilakukan, Antifungal Activity of Alphamangostin Againts Candida albicans, menunjukkan bahwa daya hambat Candida oleh alpha-mangostin lebih baik dari clotrimazole dan nystatin. Hal ini dikarenakan alpha-mangostin dapat beraksi dengan menyerang struktur dan fungsi sel jamur dan komponen lipid utama dalam me mbran dan bagian terpenting dari kehidupan jamur. 14,15

\section{KESIMPULAN}

Ekstrak kulit buah manggis efektif menghambat jamur Candida albicans dengan zona hambat terbesar yaitu 14,06 $\mathrm{mm}$ pada konsentrasi 12,5\%. Hal ini dikarenakan dipengaruhi oleh besarnya zat aktif dalam suatu konsentrasi larutan, semakin besar konsentrasinya maka jumLah kandungan zat aktif yang dikeluarkan akan semakin banyak sehingga semakin tinggi konsentrasi suatu bahan ekstrak maka semakin efektif pula mikroorganisme yang akan terbunuh. Tetapi pada kontrol positif jauh lebih besar bila dibandingkan dengan konsentrasi ekstrak kulit buah manggis $0,1 \% 0,5 \% 2,5 \%$ dan $12,5 \%$.

\section{DAFTAR PUSTAKA}

1. Nurhidayat $O$, et al. Perbandingan media power point dengan flip chart dalam meningkatkan pengetahuan kesehatan gigi dan mulut. Unnes Journal of Public Health, 2012;1(1):31-35.

2. Adwan $G$, et al. Assessment of antifungal activity of herbal and conventional toothpastes against clinical isolates of Candida albicans. Asian Pacific Journal of Tropical Biomedicine, 2012;2(5):375-379. 
3. Apriasari ML. Kumpulan Kasus Penyakit Mulut. Jakarta: Salemba Medika, 2013,p.1.

4. Khafidhoh Z, et al. Efektivitas infusa kulit jeruk purut (Citrus hystrix DC.) terhadap pertumbuhan Candida albicans penyebab sariawan secara in vitro. University Research Coloquium, 2015.

5. Wijaya $\mathrm{CH}$, et al. Penghambatan cajuputs candy terhadap viabilitas khamir Candida albicans secara in vitro. J Teknol dan Industri Pangan, 2014;25(2):58-167.

6. Agnita $P$, et al. Perbedaan daya hambat ekstrak dan rebusan daun jarak pagar (Jatropha curcas L.) terhadap pertumbuhan Candida albicans (Robin) Berkhout. Artikel IImiah, 2014.

7. Okonkwo EC, et al. Prevalence of oral Candida albicans infection in HIV sero-positive patients in Abakaliki. American Journal of Life Sciences, 2013;1(2):72-76.

8. Hakim L, Ramadhian R. Kandidiasis oral. Majority, 2015;4(8):53- 57.

9. Riwandy A, et al. Aktivitas antibakteri ekstrak air kelopak bunga rosella (Hibiscus sabdariffa L.) terhadap pertumbuhan Streptococcus mutans secara In
Vitro. Dentino Jurnal Kedokteran Gigi, 2014;2(1):60-64.

10. Muslimah U, Guntarti A. Ekstrak etanol kulit buah manggis(Garcinia mangostana L.) sebagai antioksidan alami pada minyak krengseng. Universitas Ahmad Dahlan, 2014.p. 21-30.

11. Windarini LGE. Skrining fitokimia ekstrak methanol kulit buah manggis (Garcinia mangostana L.). Universitas Udayana, 2013, p.1-8.

12. Andayani $R$, et al. Potensi daya hambat ekstrak kulit buah manggis (Garcinia mangostana L.) terhadap pertumbuhan Candida albicans. Journal of Syiah Kuala Dentistry Society, 2016;(1)1:13-20.

13. Putra INK. Potensi ekstrak tumbuhan sebagai pengawet produk makanan. Media Ilmiah Teknologi Pangan, 2014;(1)1:8195.

14. Kaomongkolgit $\mathrm{R}$, et al. Antifungal Activity of Alpha-mangostin Against Candida albicans. Journal of Oral Science, 2009;51(3):401-406.

15. Kaomongkolgit $\mathrm{R}$, Jamdee $\mathrm{K}$. Inhibitory Effect of Alpha-mangostin on Adhesion of Candida albicans to Denture Acrylic. The Open Dentistry Journal, 2015;9: 388-392. 